\title{
VARIABILITY OF MORPHOMETRIC LEAF TRAITS IN SMALL-LEAVED LINDEN (TILIA CORDATA MILL.) UNDER THE INFLUENCE OF AIR POLLUTION
}

\author{
PIOTR KosiBA \\ Department of Ecology, Biogeochemistry and Environmental Protection, \\ Institute of Plant Biology, Wroclaw University \\ Kanonia 6/8, 50-328 Wrocław, Poland \\ e-mail: kosibap@biol.uni.wroc.pl
}

(Received: December 5, 2006. Accepted: September 3, 2007)

\begin{abstract}
The study concerns the ecological responses of Tilia cordata Mill. to pollution and describes the advantages of estimating of the degree of environmental pollution. The aim was, to find out whether the degree of pollution conforms to the contents of the investigated elements in leaves, the assessment of variability of morphometric leaf traits and the cationic equilibrium values. The study has shown a statistically significant differentiation between the analysed sites in respect of dust fall, concentrations of elements in soils and leaves, morphometric traits of leaves and the cationic equilibrium. The hierarchical tree plot of cluster analysis qualified the sites as polluted and non-polluted. In polluted sites the contents of metals in leaves were significantly higher and the cationic equilibrium in leaves was disturbed. The surface, width and asymmetry of leaves, and also the variability of these measures were higher in polluted sites. In sites, which are not directly affected by pollution the cationic equilibrium is close to the const. value, whereas leaf traits have shown the lowest values and a considerably lower variability. The investigations show that leaf traits and cationic equilibrium correspond to the level of pollution and can be used as a tool for evaluation of the environment status.
\end{abstract}

KEY WORDS: Tilia cordata, morphometry, leaf parameters, biometric analysis, bioindicator, pollution.

\section{INTRODUCTION}

Human population and its increasing consumption of natural resources threaten the ecosystems (Daily 1997). Industrialization and urbanization are chronic factors disturbing the homeostasis of the natural environment. However, owing to the buffering capacity and efficiency of the ecosystem, its normal structure and function are maintained (Lee et al. 2004). Nowadays, the ecosystems are often influenced by wet and dry air deposits (Fabiszewski 1983; Zakrzewski 1995; Alloway and Ayres 1999; Fabiszewski and Kwiatkowski 2002; Bytnerowicz et al. 2003; Bell and Treshow 2004; Walker et al. 2005). Changes caused by pollution occur even in areas far away from point-source emitters (Kurzydło 1994; Helios-Rybicka 1996; Fabiszewski and Brej 2000; Madej 2002; Kosiba 2007). In areas where lichens and mosses are lacking, trees are used as biomonitors of air pollution (Fabiszewski et al. 1987; Barghigiani et al. 1991; Dmuchowski and Bytnerowicz 1995; Alfami et al. 1996; Fisher et al. 2002; Madejon et al. 2004). For evaluation of the degree of environmental pollution both coniferous and deciduous trees are used (Kovács 1992; Sawidis et al. 1995; Batic et al. 1999; Abo- al et al. 2004; Cicek and Koparal 2004). The symptoms of pollution impact upon trees are investigated in physiological, biochemical, morphological and cytogenetic aspects (Premoli 1996; Nabais et al. 1999; Iannotti et al. 2000; Hagen-Thorn et al. 2004; Tretyakova and Noskova 2004; Yilmaz and Zengin 2004). In scientific literature such trees as oak, ash, birch, beech, spruce, pine are often objects of investigations on bioindication, but morphometric investigations (Zelditch et al. 2004) of individual ecological traits of tree leaves are still rather sparse. According to Premoli (1996), leaf morphology represents an important set of vegetative characters that are used in taxonomic, developmental and ecological studies. When growth processes are perturbed, the developing phenotypic traits are often affected.

In the case of Tilia cordata, the interest is much smaller, though it is a commonly found ornamental species on roads and in cities (Białobok 1991; Seneta 1987; Seneta and Dolatowski 2005). It reveals a considerable tolerance for soil conditions, hardiness from frost, and in comparision with other species of Tilia, it is more sensitive to industrial, urban and vehicle pollutions (Hrynkiewicz-Sudnik 1976; Antipov 1979). According to the mentioned authors, pollution causes 
developmental disturbances of the tree crown, acute and chronic damages of leaves and premature defoliation.

That is why the undertaken investigations were directed to evaluation of pollution effects on $T$. cordata leaves.

The hypothesis was, that biometric traits of Tilia cordata leaves and cationic equilibrium depend on the degree of environmental pollution. The answer to the hypothesis could be obtained through: determination of dust fall level, heavy metals in soil and leaves from examined sites, determination of, how pollution affects the morphometrics traits of leaves and the cationic equilibrium and finding out, whether the image and numerical tools can be useful in this type of ecological studies.

\section{MATERIALS AND METHODS}

\section{Study area, data collection and chemical analyses}

The investigations were carried out in southwestern Poland on the territory of the Province of Lower Silesia $\left(19948 \mathrm{~km}^{2}\right)$. The object of researches was Tilia cordata Mill. Lower Silesia Province is affected by various dustgaseous pollutions from point-source emitters, mainly situated in the "Black Triangle" (Bogatynia, and also from the Czech Republic and Germany), LGOM - Legnicko-Głogowski Okręg Miedziowy (Legnica-Głogów Copper District) (Raport 2006) and urban pollution.

A short characterization of meteorological conditions and pollution emission for the area of Lower Silesia and its districts is presented according to data of Raport (2006). The mean air temperature for Wrocław, Legnica, Zgorzelec, Jelenia Góra and Kłodzko ranged in August within 15$-18^{\circ} \mathrm{C}$ and rain fall within $40-75 \mathrm{~mm}$. The total load of pollution emission from industrial plants for Lower Silesia was: (in thousands $\mathrm{Mg} /$ year): dusts $-8.6, \mathrm{SO}_{2}-56.3, \mathrm{NO}_{\mathrm{X}}$ $-22.8, \mathrm{CO}-10.0, \mathrm{CO}_{2}-16559.1$. During the last decade there occurred a sevenfold reduction of them. According to Report (2006), the total emission of pollution in districts, in which the investigation sites were situated, was different (Table 1).

The detailed meteorological data and measurments of dust-gaseous emissions recorded by permanent and mobile measurment stations are presented in Raport (2006).

The investigations were carried out in August 2006. In Lower Silesia chosen were 16 sites (Fig. 1).

The sites were selected according to their localization in relation to point-source emitters, wind direction (SW and W), which differentiate the sites in respect of distribution and range of emission.
The degree of pollution of the investigated sites has been determined by total dust fall using the sedimentation method (Skinder 1991). The obtained results were expressed in $\mathrm{g}^{*} \mathrm{~m}^{-2 *}$ year $^{-1}$. The distribution of dust fall quantities is presented on a contour map using the coordinates of sampling sites, and is based on the mean values of each site. The map was drawn by means of the isolines method by means of the Kriging method of gridding with the computer program Surfer 8.03 (Golden Software 2004). Colours and scale were selected as to clearly illustrate the changes of the dust fall distribution.

Every site is represented by five $T$. cordata individuals of similar height $(12-14 \mathrm{~m})$ and trunk circumference (1.07$-1.27 \mathrm{~m}$ ) measured at height of $1.80 \mathrm{~cm}$ above ground surface, altogether 80 specimens. All specimens grow in the studied sites as ornamental trees and the distance between them is minimum $40 \mathrm{~m}$. All of them were singly objects in the site area, not shaded by other biological and urbanization components of the environment. From every specimen taken were eight $1 \mathrm{~m}$ long apical shoot sections, from the height of $5 \mathrm{~m}$, from various sides of the external zone of the tree crown. The numbers of leaves ranged from 63 to 94 on each shoot. Fresh leaves were used for morphometric measurements. Using the scanning technique in scale 1:1 measured were: leaf surface $\left(\mathrm{cm}^{2}\right)$, width $(\mathrm{cm})$ and leaf symmetry (symmetry range from 0 to 1 ). For scanning and measurements of leaf traits the program for automatic morphometry digiShape (Cortex Nova 2005) was used. According to Moreno-Sanchez (2004), the use of image-numerical computer techniques make additional important arguments in ecological studies.

Next, the collected leaves were cleaned of organisms and other debris, and were washed manually in distilled water for several minutes by shaking out. According to Aboal et al (2004), the cleaning allows to eliminate the fractions associated with aerosols from the surface of the leaves. Wyttenbach et al. (1990) found that the fraction can amount to more than $60 \%$ of the total concentration of the elements. After drying to constant mass in temperature of 70 $-90^{\circ} \mathrm{C}$ the samples of leaves were homogenized in an agate mortar and burned in a muffle furnace in temperature of $450^{\circ} \mathrm{C}$ for 8 hours. The resulting ash samples $(250 \mathrm{mg})$ were digested in $5 \mathrm{ml}$ concentrated $\mathrm{HNO}_{3}$, and then burned in a microwave oven CEM-MARS 5. After dilution to $25 \mathrm{ml}$ with bi-distilled water, analyzed were: total level of $\mathrm{Al}, \mathrm{Be}$, $\mathrm{Cr}, \mathrm{Cu}, \mathrm{Fe}, \mathrm{Mg}, \mathrm{Mn}, \mathrm{Ni}, \mathrm{Pb}, \mathrm{Zn}$ by flame atomic absorption spectrophotometry (GBC Scientitic Equipment Pty. Ltd. Model AVANTA PM), and B, Cd, Ge were measured by the electrothermal atomic absorption spectrophotometry

TABLE 1. The total amount of dust and gaseous emissions in districts of Lower Silesia.

\begin{tabular}{|c|c|c|c|c|c|}
\hline District / Site no. & $\begin{array}{c}\text { Dust PM10 } \\
{\left[\mu \mathrm{g} / \mathrm{m}^{3}\right]}\end{array}$ & $\begin{array}{l}\text { Dust emission } \\
\text { [Mg/year }]\end{array}$ & $\begin{array}{l}\text { Gaseous emission } \\
\text { [thousands } \mathrm{Mg} \text { /year] }\end{array}$ & $\begin{array}{c}\mathrm{SO}_{2} \text { emission } \\
{[\mathrm{Mg} / \text { year }]}\end{array}$ & $\begin{array}{c}\mathrm{NO}_{\mathrm{X}} \text { emission } \\
{[\mathrm{Mg} / \text { year }]}\end{array}$ \\
\hline Wrocławski / 1 & Lack of data & $101-150$ & $200.1-1000$ & $1000.1-5000$ & $500.1-1000$ \\
\hline Zgorzelecki / 2, 14-16 & 16.6-29.9 & $>2000$ & $>5000$ & $>10000$ & $>5000$ \\
\hline Średzki / 3 & lack of data & $101-150$ & $10.1-50$ & $250.1-500$ & $50.1-100$ \\
\hline Lubiński / 9 & 23.6-37.4 & $1001-2000$ & $200.1-1000$ & $1000.1-5000$ & $250.1-500$ \\
\hline Legnica / 10-12 & $31-35.6$ & $101-150$ & 200.1-1000 & $1000.1-5000$ & $250.1-500$ \\
\hline Bolesławiecki / 5 & 16.8 & $501-1000$ & $50.1-100$ & 250.1-500 & $100.1-250$ \\
\hline Wrocław / 6-8 & $39.3-43.1$ & $501-1000$ & $1000.1-5000$ & $5000.1-10000$ & $1000.1-5000$ \\
\hline Lubański / 13 & $8-22.3$ & $101-150$ & 10.1-50 & 50.1-100 & 50.1-100 \\
\hline
\end{tabular}






Fig. 1. Location of Tilia cordata sampling sites in Lower Silesia

using the attachment (Model GF 3000) with AVANTA $\mathrm{PM}$. For analysis of $\mathrm{Ca}, \mathrm{K}, \mathrm{Na}$ the flame atomic emission spectrophotometry (Jenway Model PFP7) was used. The results are expressed in $\mathrm{mg}^{*} \mathrm{~kg}^{-1}$ dry mass of leaves.

At the same time as leaves samples of $T$. cordata, soil samples were taken from the area off the canopy tree-tops of each tree at depth of 10-20 cm, using a plastic shovel. Three subsamples were taken around the trunk to make a composite soil sample per tree. After removing litter and other remains, the air-dried samples were homogenized in an agate mortar and sifted through a plastic sieve of mesh diameter $1 \mathrm{~mm}$. The soil samples $(250 \mathrm{mg})$ were digested with $5 \mathrm{ml}$ nitrohydrochloric acid in proportion $3: 1$, and burned. After dilution by bi-distilled water to $25 \mathrm{ml}$, the samples were used for chemical analysis of $\mathrm{Al}, \mathrm{B}, \mathrm{Be}, \mathrm{Cd}$, $\mathrm{Cr}, \mathrm{Cu}, \mathrm{Ge}, \mathrm{Mn}, \mathrm{Ni}, \mathrm{Pb}$ and $\mathrm{Zn}$, using the same methods and measuring devices as in the case of $T$. cordata leaves. The results were expressed in $\mathrm{mg}^{*} \mathrm{~kg}^{-1}$ dry weight basis.

All elements were measured against standards and blanks. The accuracy of the analytical method was assessed by carrying out analyses of certified reference materials NCS DC 73350 Poplar leaves.

All chemical analyses of leaves and soils samples were carried out in three measuring repetitions.

\section{Statistical analyses}

For leaf traits calculated were the following values: minimum, maximum, arithmetic mean, standard deviation and the coefficient of variability $\mathrm{V}(\%)$.
The goodness of fit of empirical data to the normal distribution has been verified using the Shapiro-Wilk's test, which is the preferred and effective test for evaluation of features normality for a small number of samples (Conti et al. 2005). In cases of normal distribution of the analyzed features, the statistical-mathematical verification of results has been based on parametric tests. The differentiation of sites in respect of elements concentrations in soil, leaves and morphometric leaf traits has been analyzed by the one-way ANOVA with the F test. Also the LSD values were calculated. The relationships between elements were expressed by Pearson's coefficient (r), and equation of regression. The significance of variability of the calculated value of cationic equilibrium $\left(\mathrm{E}_{\mathrm{C}}\right)$ in relation to its constant value $\left(\mathrm{E}_{\text {const. }}=12.515\right)$ was verified using the t-test for a single sample. The similarity of sites in respect of chemical soil properties and in respect of elements contents in leaves of $T$. cordata was analysed using the method of cluster analysis. The Ward's method of amalgamation was applied and the method of Euclidean distance $\left((x, y)=\Sigma_{i}\right.$ $\left(\mathrm{x}_{\mathrm{i}}-\mathrm{y}_{\mathrm{i}}\right)$ was used as measure of similarity. Significance of clusters was defined by Sneath index (33.3 and 66.7\% respectively) (Massard and Kaufman 1983). The ordination of sites at fixed criteria of cluster analysis is graphically presented by dendrograms. On the basis of chemical analysis of leaves samples, the constant of cationic equilibrium was calculated (Czarnowski 1977, 1989). According to the mentioned author, in temperate-climate and in natural conditions the cationic equilibrium amounts to 
12.515 in many plant species. This relation is expressed in the mathematical model:

$$
\Sigma c_{\mathrm{i}} \sqrt{\frac{\left[E_{i}\right]}{\sum[E]}}=\text { const. }
$$

where: $C_{i}$ is the interdependent weight of cation $E_{i}, E-$ content of given element.

All calculations and the statistical verification of results were carried out at significance level of $\mathrm{p}<0.05$ using the program STATISTICA 7.1 (StatSoft, Inc. 2005) according to the principles of data analyses given by Legendre and Legendre (1998), Zar (1999), Sokal and Rohlf (2003). The numerical techniques applied in ecological investigations, i.e. collection of quantitative information on objects analysis and interpretation of results, as well as all numerical procedures, were based on principles given by Brower et al. (1998).

\section{RESULTS AND DISCUSSION}

\section{ANOVA analysis of T. cordata sites in respect of dust fall, soil properties and relationships}

The values of dust fall is statistical significance between the sites of $T$. cordata (Table 2).

Through interpolation of dust fall results the degree of pollution of sites was determined. It is presented by the differentiated spatial distribution of dust fall (Fig. 2).

It was found that the sites are characterized by a broad range of dust fall ranging from 161 (site 1) to $854 \mathrm{~g}^{*} \mathrm{~m}^{-2 *}$ ye$\operatorname{ar}^{-1}$ (site 16). According to Ciechanowicz (1994), the permissible standard of dust in Poland is $200 \mathrm{~g}^{*} \mathrm{~m}^{-2 *} \mathrm{year}^{-1}$. This condition was met on sites 1 and 2, whereas in the remaining sites dust fall exceeded the permissible standard two to four times (sites 6-16).

The results of total dust fall, obtained for the analysed sites were compared with dust-fall values for districts mentio- ned in the Raport (2006). It was found that the dust fall results correspond with the measurments of total dust emissions according to that Raport. Site 16 - Bogatynia (854 $\mathrm{g}^{*} \mathrm{~m}^{-2 *}$ year $\left.^{-1}\right)$ of the highest dust fall, sites 14 and 15 (569 and $678 \mathrm{~g}^{*} \mathrm{~m}^{-2} *$ year $\left.^{-1}\right)$ approaching the highest dust fall. These sites correspond with the zone of the highest dust emission load of over $2000 \mathrm{Mg} /$ year. The lowest dust fall was recorded on site 1 - Sobótka $\left(161 \mathrm{~g}^{*} \mathrm{~m}^{-2 *}\right.$ year $\left.^{-1}\right)$ which corresponds with dust fall load of $101-150 \mathrm{Mg} / \mathrm{year}$. This is confirmed by previous studies on mosses, carried out in the same area by Kosiba (1997), Kosiba and Kolon (2002), Kosiba (2004). Thus, the results of dust fall on the investigated sites point to a relation with the magnitude of dust emissions, their reach and spatial distribution, which is connected with industrial emitters and local urban sources. Moreover, sites 14-16, situated on the so-called "Black Triangle" area are also subjected to pollutions from German and Czech point-source emitters (Helios-Rybicka 1996; Markert et al. 1996; EMEP Status Raport 2004; Raport 2006). One may suppose, that the differentiated amount of dust fall on the analysed sites will, more or less characterize the chemical status of the soils. In fact, it has been stated by correlation analysis, that the concentrations of $\mathrm{Al}, \mathrm{Be}, \mathrm{Ge}$ and $\mathrm{Pb}$ in soils depend on the amount of dust fall. The mentioned relationships are positive and statistically significant (Table 3).

These results of relationships correspond to data of Kabata-Pendias (2001), Sawicka-Kapusta et al. (2003) and Salemaa et al. (2004), and show that the quantity and quality of dust emissions affects the chemical status of the environment, in our case the soils properties.

\section{Cluster analysis of $T$. cordata sites in respect of dust fall and soil properties}

The applied method of cluster analysis determined the similarity of sites in respect of dust fall and contents of $\mathrm{Al}$, $\mathrm{B}, \mathrm{Be}, \mathrm{Cd}, \mathrm{Cr}, \mathrm{Cu}, \mathrm{Ge}, \mathrm{Mn}, \mathrm{Ni}, \mathrm{Pb}$ and $\mathrm{Zn}$ in soil samples (Fig. 3).

This analysis is suitable for geochemical investigations and is more often used than other classification methods

TABLE 2. Dust fall $\left(\mathrm{g}^{*} \mathrm{~m}^{-2} * \mathrm{year}^{-1}\right)$ and element concentrations $\left(\mathrm{mg}^{*} \mathrm{~kg}^{-1}\right)$ in soil samples.

\begin{tabular}{|c|c|c|c|c|c|c|c|c|c|c|c|c|}
\hline Site & Dust fall & $\mathrm{Al}$ & B & $\mathrm{Be}$ & $\mathrm{Cd}$ & $\mathrm{Cr}$ & $\mathrm{Cu}$ & $\mathrm{Ge}$ & $\mathrm{Mn}$ & $\mathrm{Ni}$ & $\mathrm{Pb}$ & $\mathrm{Zn}$ \\
\hline 1 & 161 & 18.2 & 26 & 0.21 & 0.21 & 3.8 & 18 & 0.04 & 164 & 2.9 & 6.3 & 74 \\
\hline 2 & 187 & 12.1 & 37 & 0.17 & 0.12 & 5.3 & 24 & 0.06 & 182 & 3.3 & 4.6 & 53 \\
\hline 3 & 238 & 9.9 & 64 & 0.24 & 0.41 & 6.1 & 14 & 0.08 & 267 & 2.7 & 6.1 & 95 \\
\hline 4 & 291 & 11.4 & 91 & 0.16 & 0.27 & 8.4 & 35 & 0.12 & 304 & 2.4 & 4.2 & 109 \\
\hline 5 & 384 & 16.4 & 54 & 0.10 & 0.14 & 6.8 & 21 & 0.07 & 344 & 3.8 & 7.2 & 163 \\
\hline 6 & 544 & 18.4 & 93 & 0.44 & 0.34 & 15.2 & 84 & 0.37 & 136 & 7.7 & 13.2 & 332 \\
\hline 7 & 466 & 16.7 & 75 & 0.64 & 0.51 & 12.4 & 96 & 0.42 & 187 & 9.1 & 10.2 & 273 \\
\hline 8 & 452 & 26.7 & 102 & 0.71 & 0.37 & 13.4 & 67 & 0.51 & 194 & 8.6 & 17.7 & 309 \\
\hline 9 & 482 & 34.3 & 170 & 1.34 & 2.84 & 68.1 & 264 & 1.48 & 341 & 21.4 & 65.1 & 548 \\
\hline 10 & 570 & 27.2 & 142 & 1.61 & 3.66 & 94.1 & 384 & 1.11 & 284 & 17.3 & 83.0 & 395 \\
\hline 11 & 522 & 25.7 & 108 & 1.74 & 6.11 & 73.1 & 271 & 2.24 & 365 & 31.4 & 58.9 & 621 \\
\hline 12 & 563 & 24.3 & 187 & 1.66 & 3.91 & 79.4 & 289 & 1.84 & 316 & 24.8 & 66.1 & 438 \\
\hline 13 & 708 & 30.1 & 64 & 2.14 & 0.41 & 11.2 & 127 & 3.88 & 245 & 2.0 & 46.1 & 192 \\
\hline 14 & 569 & 47.0 & 51 & 1.74 & 0.31 & 14.1 & 138 & 4.21 & 297 & 2.6 & 84.7 & 132 \\
\hline 15 & 678 & 38.7 & 35 & 1.82 & 0.27 & 9.3 & 94 & 5.11 & 184 & 3.2 & 35.7 & 191 \\
\hline 16 & 854 & 41.6 & 68 & 2.01 & 0.40 & 10.1 & 78 & 4.79 & 311 & 2.4 & 52.2 & 141 \\
\hline $\mathrm{F}$ & 87.1 & 46.2 & 94.1 & 20.1 & 66.5 & 152.4 & 14.7 & 60.8 & 184.5 & 45.7 & 94.5 & 15.2 \\
\hline $\mathrm{p}$ & $* *$ & $* *$ & $* *$ & $* * *$ & $* * *$ & $* *$ & $* * *$ & $* *$ & $*$ & $* * *$ & $* * *$ & $* *$ \\
\hline LSD & 34.1 & 2.3 & 6.4 & 0.3 & 0.2 & 2.2 & 5.7 & 0.1 & 38.7 & 1.0 & 3.9 & 22.0 \\
\hline
\end{tabular}

$\mathrm{F}$ - value of F-test; $\mathrm{p}$ - statistical significance: *** $\mathrm{p}<0.001, * * \mathrm{p}<0.01, * \mathrm{p}<0.05$; LSD: value of Least Significant Difference 


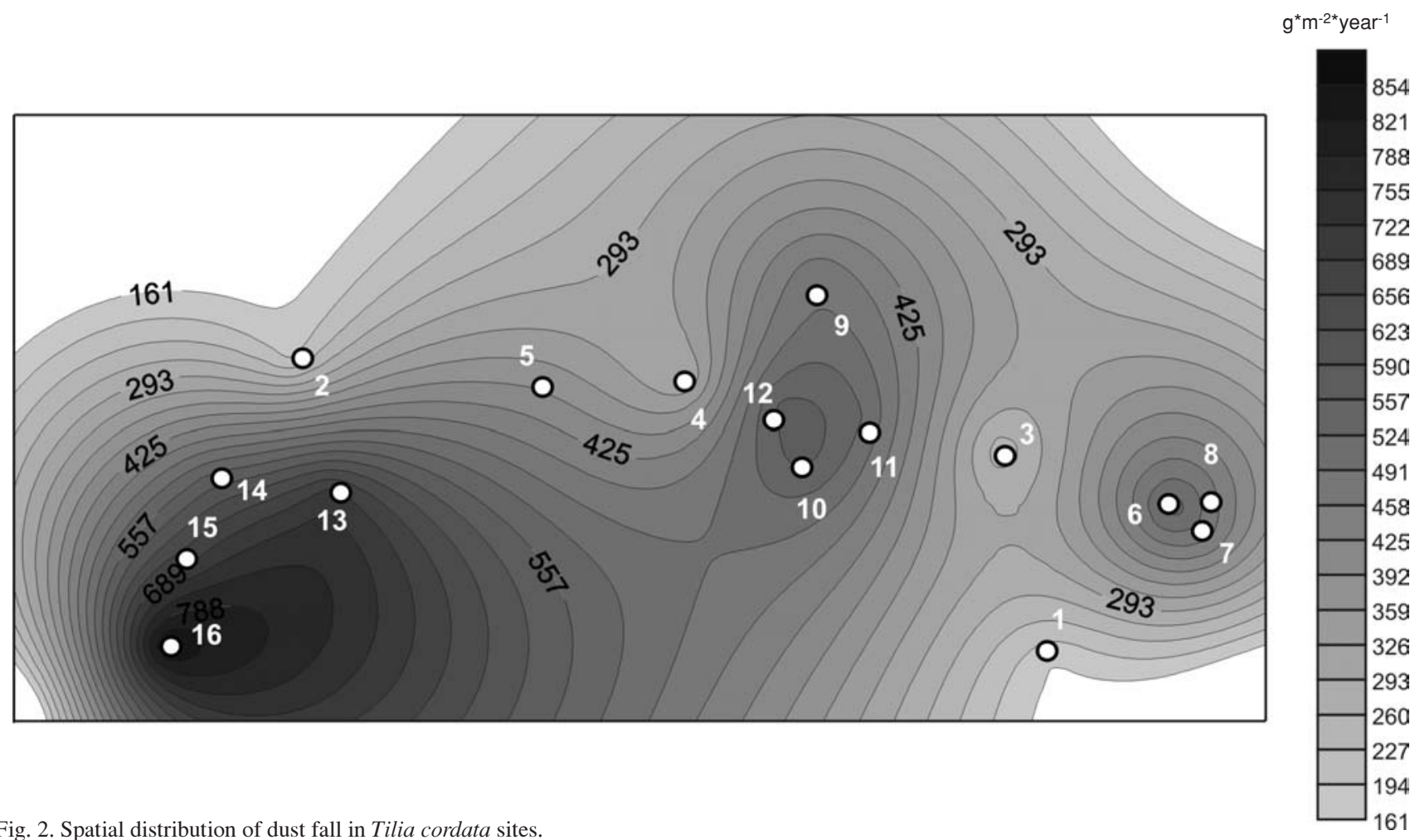

TABLE 3. Relationships of dust fall, element concentrations in soil and leaf samples.

\begin{tabular}{lccc}
\hline Relationships & $\begin{array}{c}\text { Equation } \\
\text { of regression }\end{array}$ & $\mathrm{r}$ & $\mathrm{p}$ \\
\hline
\end{tabular}

\begin{tabular}{cccc} 
& Between amount of dust fall and element concentrations in soils \\
$\mathrm{Al}$ & $\mathrm{y}=3.32+0.05 \mathrm{x}$ & 0.77 & $* * *$ \\
$\mathrm{Be}$ & $\mathrm{y}=-0.61+0.004 \mathrm{x}$ & 0.86 & $* * *$ \\
$\mathrm{Ge}$ & $\mathrm{y}=-2.14+0.01 \mathrm{x}$ & 0.82 & $* * *$ \\
$\mathrm{~Pb}$ & $\mathrm{y}=-12.23+0.10 \mathrm{x}$ & 0.64 & $* *$ \\
\hline
\end{tabular}

\begin{tabular}{lccc}
\hline \multicolumn{4}{c}{ Between amount of dust fall and element concentrations in leaves } \\
$\mathrm{Al}$ & $\mathrm{y}=-28.57+0.86 \mathrm{x}$ & 0.68 & $* *$ \\
$\mathrm{~B}$ & $\mathrm{y}=-0.88+0.09 \mathrm{x}$ & 0.63 & $* *$ \\
$\mathrm{Be}$ & $\mathrm{y}=-0.27+0.001 \mathrm{x}$ & 0.78 & $* * *$ \\
$\mathrm{Ge}$ & $\mathrm{y}=-0.72+0.003 \mathrm{x}$ & 0.71 & $* *$ \\
$\mathrm{Zn}$ & $\mathrm{y}=18.78+0.07 \mathrm{x}$ & 0.63 & $* *$ \\
\hline
\end{tabular}

\begin{tabular}{lccc}
\hline \multicolumn{5}{c}{ Between element concentrations in soil and in leaves } \\
$\mathrm{Al}$ & $\mathrm{y}=43,26+13.74 \mathrm{x}$ & 0.63 & $* *$ \\
$\mathrm{~B}$ & $\mathrm{y}=11.55+0.34 \mathrm{x}$ & 0.61 & $*$ \\
$\mathrm{Be}$ & $\mathrm{y}=0.05+0.29 \mathrm{x}$ & 0.69 & $* *$ \\
$\mathrm{Cd}$ & $\mathrm{y}=0.43+0.52 \mathrm{x}$ & 0.87 & $* * *$ \\
$\mathrm{Cr}$ & $\mathrm{y}=0.05+0.01 \mathrm{x}$ & 0.92 & $* * *$ \\
$\mathrm{Cu}$ & $\mathrm{y}=3.39+0.05 \mathrm{x}$ & 0.85 & $* * *$ \\
$\mathrm{Ge}$ & $\mathrm{y}=0.01+0.33 \mathrm{x}$ & 0.85 & $* * *$ \\
$\mathrm{Ni}$ & $\mathrm{y}=0.53+0.33 \mathrm{x}$ & 0.93 & $* * *$ \\
$\mathrm{~Pb}$ & $\mathrm{y}=5.08+0.19 \mathrm{x}$ & 0.62 & $* *$ \\
$\mathrm{Zn}$ & $\mathrm{y}=28.84+0.09 \mathrm{x}$ & 0.75 & $* * *$ \\
\hline
\end{tabular}

$\mathrm{r}$ - value of correlation coefficient;

$\mathrm{p}-$ statistical significance: $* * * \mathrm{p}<0.001, * * \mathrm{p}<0.01, * \mathrm{p}<0.05$

(Hongijn et al. 1995). The clustering method enabled to determine the proper structure of data, which divided them into four groups of sites A, B, C and D, and revealed their differentiated similarity (Table 4).

$T$. cordata sites from group A were least similar to sites of group D, B and C in respect of the amount of dust fall and metals contents in the soils.
Sites 1-5 of group A occupy extreme positions in the dendrogram (Fig. 3). They show the smallest dust fall and contents of metals. Sites 9-12 of group D, occupy the left side of the dendrogram, and are characterized by high dust fall and the highest contents of $\mathrm{B}, \mathrm{Cd}, \mathrm{Cr}, \mathrm{Cu}, \mathrm{Mn}, \mathrm{Ni}, \mathrm{Pb}$ and $\mathrm{Zn}$, and several times higher contents of $\mathrm{Al}, \mathrm{Be}$ and $\mathrm{Ge}$ in relation to group A. Sites of groups B and C occupy the center of the dendrogram and differ between themselves. The soils from sites of group $\mathrm{C}$ have the highest dust fall and contents of $\mathrm{Al}, \mathrm{Be}$ and $\mathrm{Ge}$ in the soils. The remaining metal concentrations in the soils are several times higher then soils of group A. Sites of group B represent average values of dust fall and metals contents in soils, a little higher in relation to sites of group A. Taking into consideration the results of the cluster analysis, as well as the significant variability of results, the lowest and highest value of dust fall and metal contents in soil of the investigated $T$. cordata sites, it was found that sites 9-12 (group D-LGOM) and 13-16 (group C - "Black Triangle") are the most polluted and are under the influence of dust emission from point-sources emitters.

The clustering of sites (groups A, B, C and D) shows a wide range in respect of metals concentrations in soils. The studied sites of group A showed low or average contents of metals' value, which according to Lityński and Jurkowska (1982), Markert (1992), Kabata-Pendias and Pendias (1999), Kabata-Pendias (2001), Hagen-Thorn et al. (2004), Cicek and Kopral (2004), Shparyk and Parpan (2004) are characteristic for clean or relatively clean soils. On the contrary, the concentrations of these elements in soils from polluted sites, forming group B, C and D, are high and exceed the means and value ranges in relation to typical non-polluted soils. 


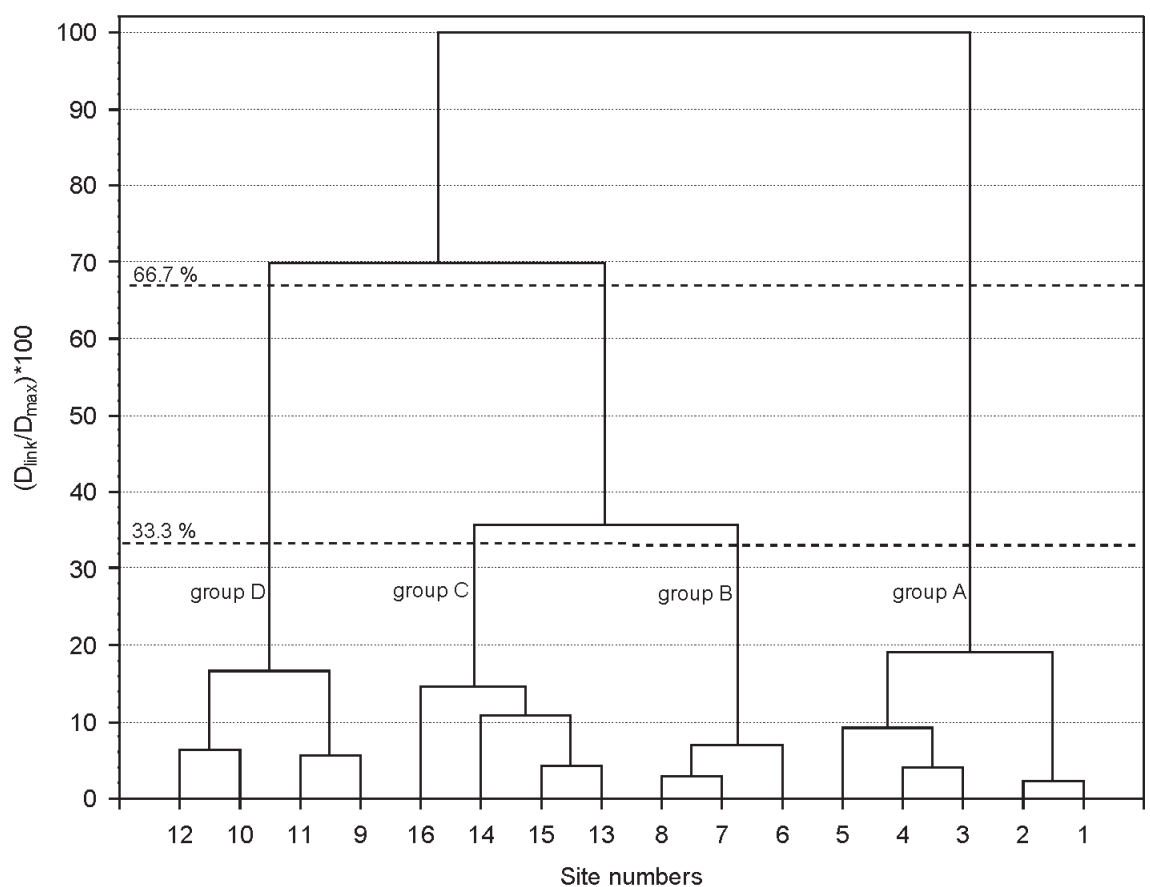

Fig. 3. Dendrogram of sites in respect of dust fall and element concentrations in soils.

TABLE 4. Sites grouping and location in respect of type of pollution from point-source emitters.

\begin{tabular}{|c|c|c|c|}
\hline Non directly affected by point-source emitters & \multicolumn{3}{|c|}{ Affected by type of point-source emitters } \\
\hline $\begin{array}{c}\text { A } \\
\text { (Clean/Relatively clean) }\end{array}$ & $\begin{array}{c}\text { B } \\
\text { (Urban) }\end{array}$ & $\begin{array}{c}\mathrm{C} \\
\text { ("Black Triangle") }\end{array}$ & $\begin{array}{c}\text { D } \\
(\mathrm{LGOM})\end{array}$ \\
\hline $\begin{array}{l}1 \text { - Sobótka } \\
2 \text { - Węgliniec } \\
3 \text { - Środa Śląska } \\
4 \text { - Chojnów } \\
5 \text { - Bolesławiec }\end{array}$ & $6 \div 8-$ Wrocław & $\begin{array}{l}13 \text { - Lubań } \\
14 \text { - Zgorzelec } \\
15 \text { - Zawidów } \\
16 \text { - Bogatynia }\end{array}$ & $\begin{array}{l}9 \text { - Lubin } \\
10 \div 12 \text { - Legnica }\end{array}$ \\
\hline
\end{tabular}

A, B, C, D - groups of sites; $1 \div 16$ - site numbers and names

\section{ANOVA analysis of sites in respect of metals contents in $T$. cordata leaves and relationships}

The sites analysed in respect of metals contents in leaves occur in one climatic zone and are localized in the area of Lower Silesia which is characterized by similar meteorological conditions (Raport 2006). According to Herpin et al. (1996), that fact enables to compare the results between them.

A statistical significance of metals contents in leaves was found between the analyzed sites (Table 5).

From sets of mean values (Tables 2, 3 and 5) it is evident that sites of higher dust fall and higher contents of elements in soil correspond with higher contents of these elements in leaves. The counted relationships (Table 3 ) revealed, that the concentration of metals in soils affects the contents of the same elements in leaves of T. cordata. All cases of relationships, except of $\mathrm{Mn}$, are positive and statistically significant. Kabata-Pendias and Pendias (1999) and Kabata-Pendias (2001) mention that aerosol of metals pollute the soil and air, and finally affect the plants. Brej and Fabiszewski (2003) found that higher terrestrial plants reveal a variable and sometimes specific ability to absorb elements from soil. According to Harrisson and Chirgawi (1989), Bache et al. (1991), Markert (1992), Marschner (1995), Mengel and Kirby (2001) this final effect caused by pollution is conditioned by various factors, which differentiate the concentration of elements in plant, for example: size and mass of the particle, kind of contamination, climatic conditions, wind speed, moisture level, orientation of leaves in space and their morphological traits. All these statements of the above mentioned authors are also reflected in the relationships found in the present study.

\section{Cluster analysis of sites in respect of metals contents in T. cordata leaves}

Like in the case of soil properties, the similarity of $T$. cordata sites in respect of $\mathrm{Al}, \mathrm{B}, \mathrm{Be}, \mathrm{Cd}, \mathrm{Cr}, \mathrm{Cu}, \mathrm{Ge}, \mathrm{Mn}$, $\mathrm{Ni}, \mathrm{Pb}$ and $\mathrm{Zn}$ contents in leaves was analysed (Fig. 4).

The cluster analysis showed the proper structure of data, and divided them into three groups of sites $\mathrm{A}, \mathrm{B}$ and $C$ with two subgroups $C_{1}$ and $C_{2}$. The hierarchical tree revealed the least similarity of sites $1-5$ (group $\mathrm{A}$ ) in relation to sites $10,11,15$ and 16 (subgroup $C_{2}$ ). Subgroup $C_{2}$ occupies extreme positions in the dendrogram. Sites 6-8, 13-14 (group B) and 9, 12 (subgroup $\mathrm{C}_{1}$ ), located in the center of the dendrogram, are less similar to sites of groups A and D. The leaves of $T$. cordata from sites of group A are characterized by the lowest contents of metals used for cluster analysis. Sites of groups groups B and C have have several times higher and high metal concentrations in leaves in relation to sites of group A.

The leaves of $T$. cordata from sites 9-12 (groups $\mathrm{C}_{1}$ and $\mathrm{C}_{2}$ ) have the highest or high contents of $\mathrm{Al}, \mathrm{B}, \mathrm{Cd}, \mathrm{Cr}, \mathrm{Cu}$, $\mathrm{Mn}, \mathrm{Ni}, \mathrm{Pb}$ and $\mathrm{Zn}$, while leaves from sites 15 and 16 (group $\mathrm{C}_{2}$ ) show the highest contents of $\mathrm{Be}$ and $\mathrm{Ge}$, and high 
contents of the remaining metals. Thus, these two groups differ evident between themselves. This differentiation is conditioned by the type of emission, not only quantitatively, but mainly by its quality. The sites 9-12 are situated within the range of copper industry emission, whereas sites 15-16, as well as 13-14 are affected by coal and energetic pollution. The present study shows evidently that the quality of pollution depends on character of point-emission sources, which influence the metal contents in plants. The same influence of various types of pollution on plants is confirmed by Kwapuliński and Sarosiek (1988), Dahmani-Muller et al. (2000), Kabata-Pendias (2001), Spencer (2001) and Salema et al. (2004). Group B is characterized by several times lower contents of metals in leaves in relation to sites of group C.

In this study, the range of metals contents appeared to be wide. Generally, the lowest (group A) and low (group B) concentrations of metals in leaves correspond to the typical range or average values encountered in linden and other deciduous tree species. In the case of sites with the highest and high metal concentrations in leaves (group C) the metals contents are nearing the upper values or even exceed the range (Białobok 1991; Markert 1992; Markert 1993; Kabata-Pendias and Pendias 1999; Kabata-Pendias 2001; Cicek and Kopral 2004; Niinemets and Kull 2003; Shparyk and Parpan 2004; Aboal et al. 2004).

Taking into consideration all obtained above results (ANOVA of dust fall, metals contents in soil, the lowest and highest values and relationships of them, and the cluster analysis of sites in respect of metals contents in soils and leaves), one may state that sites 9 and 16 are the most polluted by point-emitters (LGOM and "Black Triangle", respectively). Sites 1 and 2 are not under the direct influence of these emitters. The remaining sites are influenced mainly by urban and industrial and coal-energetic pollution in a lower degree.

\section{Cationic equilibrium in leaves of T. cordata}

The cationic equilibrium $\left(\mathrm{E}_{\mathrm{C}}\right)$ model in leaves of $T$. corada has been analysed on the basis of the $\mathrm{Al}, \mathrm{B}, \mathrm{Ca}$, $\mathrm{Cu}, \mathrm{Fe}, \mathrm{K}, \mathrm{Mg}, \mathrm{Mn}$ and $\mathrm{Na}$. Its calculated value is in all sites statistically different from the const. value (12.515) (Table 6).

The value of cationic equilibrium in plant leaves from non-polluted temperate regions is 12.515 (Czarnowski 1977, 1989). According to this author the cation concentration in plant is a function of concentrations of other cations.

Less polluted sites 1-5 (clean/relatively clean), the average value of $\mathrm{E}_{\mathrm{C}}$ is close to the const. and its range is 13.27-13.49 (13.43 \pm 0.09$)$. For the remaining sites it is widely differentiated. The sites 6-8 (urban pollution) show higher range values 13.59-13.74 (13.67 \pm 0.08$)$. The sites 9-12 (LGOM pollution) have somewhat higher range values 13.69-13.83 (13.77 \pm 0.07$)$, whereas sites 13-16 („Black Triangle”) show the widest range of 13.43-13.93 (13.71 \pm 0.23 ) (Fig. 5).

The mentioned results show that cationic equilibrium values depend on quality of pollution. This fact is confirmed by the highest and the lowest $\mathrm{E}_{\mathrm{C}}$ values in sites $11-14$ or $15-16$, respectively. 


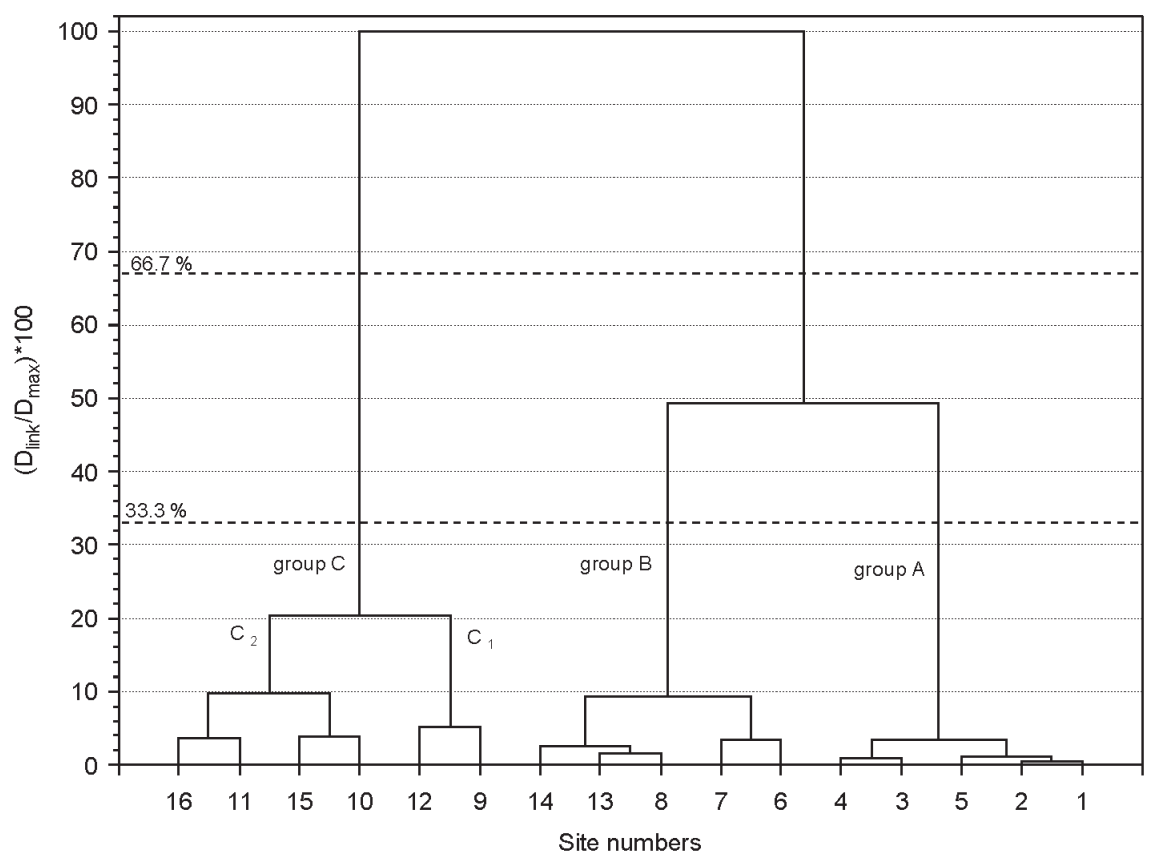

Fig. 4. Dendrogram of sites in respect of element concentrations in leaves.

TABLE 6. Relative concentrations of cations and cationic equilibrium $\left(\mathrm{E}_{\mathrm{C}}\right)$ in leaf samples (t-test to $\left.\mathrm{E}_{\text {const. }}=12.515\right)$.

\begin{tabular}{|c|c|c|c|c|c|c|c|c|c|c|c|c|}
\hline Site & $\mathrm{Ca}$ & $\mathrm{K}$ & $\mathrm{Na}$ & $\mathrm{Mg}$ & $\mathrm{Al}$ & B & $\mathrm{Mn}$ & $\mathrm{Cu}$ & $\mathrm{Fe}$ & $\mathrm{E}_{\mathrm{C}}$ & $\mathrm{t}$ & $\mathrm{p}$ \\
\hline 1 & 0.3516 & 0.5205 & 0.0687 & 0.0535 & 0.0031 & 0.0004 & 0.0010 & 0.0002 & 0.0010 & 13.46 & 8.6 & $*$ \\
\hline 2 & 0.4190 & 0.4720 & 0.0429 & 0.0617 & 0.0023 & 0.0002 & 0.0009 & 0.0001 & 0.0009 & 13.48 & 14.7 & ** \\
\hline 3 & 0.4644 & 0.4642 & 0.0440 & 0.0221 & 0.0032 & 0.0005 & 0.0007 & 0.0002 & 0.0008 & 13.49 & 20.1 & $* *$ \\
\hline 4 & 0.4922 & 0.4373 & 0.0316 & 0.0350 & 0.0022 & 0.0003 & 0.0005 & 0.0001 & 0.0008 & 13.46 & 27.4 & $* *$ \\
\hline 5 & 0.3850 & 0.5270 & 0.0332 & 0.0506 & 0.0021 & 0.0004 & 0.0008 & 0.0001 & 0.0008 & 13.27 & 19.8 & $*$ \\
\hline 6 & 0.6100 & 0.2891 & 0.0289 & 0.0635 & 0.0055 & 0.0006 & 0.0010 & 0.0002 & 0.0011 & 13.69 & 31.8 & $* *$ \\
\hline 7 & 0.6692 & 0.2220 & 0.0428 & 0.0558 & 0.0060 & 0.0004 & 0.0013 & 0.0002 & 0.0022 & 13.74 & 40.8 & $* * *$ \\
\hline 8 & 0.6953 & 0.2357 & 0.0307 & 0.0298 & 0.0061 & 0.0004 & 0.0007 & 0.0001 & 0.0013 & 13.59 & 24.3 & $* *$ \\
\hline 9 & 0.4615 & 0.2660 & 0.0493 & 0.1838 & 0.0231 & 0.0027 & 0.0023 & 0.0005 & 0.0108 & 13.73 & 32.1 & $* * *$ \\
\hline 10 & 0.5195 & 0.2608 & 0.0362 & 0.1598 & 0.0131 & 0.0014 & 0.0021 & 0.0005 & 0.0066 & 13.69 & 16.7 & $*$ \\
\hline 11 & 0.4938 & 0.2739 & 0.0510 & 0.1522 & 0.0148 & 0.0026 & 0.0032 & 0.0005 & 0.0081 & 13.83 & 14.6 & $*$ \\
\hline 12 & 0.4527 & 0.3644 & 0.0518 & 0.1006 & 0.0186 & 0.0013 & 0.0017 & 0.0005 & 0.0084 & 13.83 & 18.4 & $* *$ \\
\hline 13 & 0.3911 & 0.3249 & 0.1021 & 0.1533 & 0.0175 & 0.0021 & 0.0017 & 0.0001 & 0.0071 & 13.87 & 48.6 & $* * *$ \\
\hline 14 & 0.5376 & 0.3135 & 0.0604 & 0.0695 & 0.0122 & 0.0013 & 0.0008 & 0.0001 & 0.0047 & 13.93 & 33.8 & $* *$ \\
\hline 15 & 0.3769 & 0.4412 & 0.0446 & 0.1114 & 0.0176 & 0.0013 & 0.0011 & 0.0002 & 0.0058 & 13.60 & 19.2 & $*$ \\
\hline 16 & 0.3423 & 0.4836 & 0.0416 & 0.1179 & 0.0098 & 0.0012 & 0.0013 & 0.0001 & 0.0022 & 13.43 & 11.7 & ** \\
\hline
\end{tabular}

$\mathrm{E}_{\mathrm{C}}-$ values of cationic equilibrium; $\mathrm{t}-$ value of $\mathrm{t}$-test; $\mathrm{p}$ - statistical significance: $* * * \mathrm{p}<0.001, * * \mathrm{p}<0.01, * \mathrm{p}<0.05$

The aim of the present paper was not the analysis of physiological importance of elements and their interactions in $T$. cordata leaves. However, the information on cationic equilibrium in leaves, its stability and variability, can be used as a diagnostic tool in the estimation of chemical conditions of the environment. As is shown in the study, the concentration and establishing of the proper qualitative relations between ions, particularly heavy metals, may significantly affect the final value of cationic equilibrium. Thus, the concentrations of cations in leaves, which depend on environmental pollution, are the cause of changes in cationic equilibrium. Such impacts of pollution on various lower and higher plants were studied earlier by Samecka-Cymerman (1988), Sporek (1995), Samecka-Cymerman et al. (1997; 2000), Kwapuliński et al. (2001), Kosiba and Kolon (2002) and Kosiba (2004). These authors analyzed the cationic equilibrium in plants growing in different habitats, and showed its significantly lower values in relation to const. value in areas with higher contents of metals in envi- ronment. The present investigations show a similar trend. But, Marschner (1995) and Kabata-Pendias and Pendias (1999, 2001), Mengel and Kirby (2001), pay attention to the interactions between elements (antagonistic and synergic) in various parts of plants, which affect the final cationic equilibrium value. Hence, in future investigations concentrations of other elements and their interactions should be taken under consideration for specification of their impact on value of cationic equilibrium in polluted and nonpolluted areas, as well as along the pollution gradient.

\section{Descriptive statistics and ANOVA analysis} of morphometric traits of $T$. cordata leaves

Sites, characterized in respect of concentrations of elements in soil and leaf samples, were also compared in respect of morphometric leaf traits of $T$. cordata. It turned out that the analyzed leaf traits differ significantly between the studied sites (Table 7). 


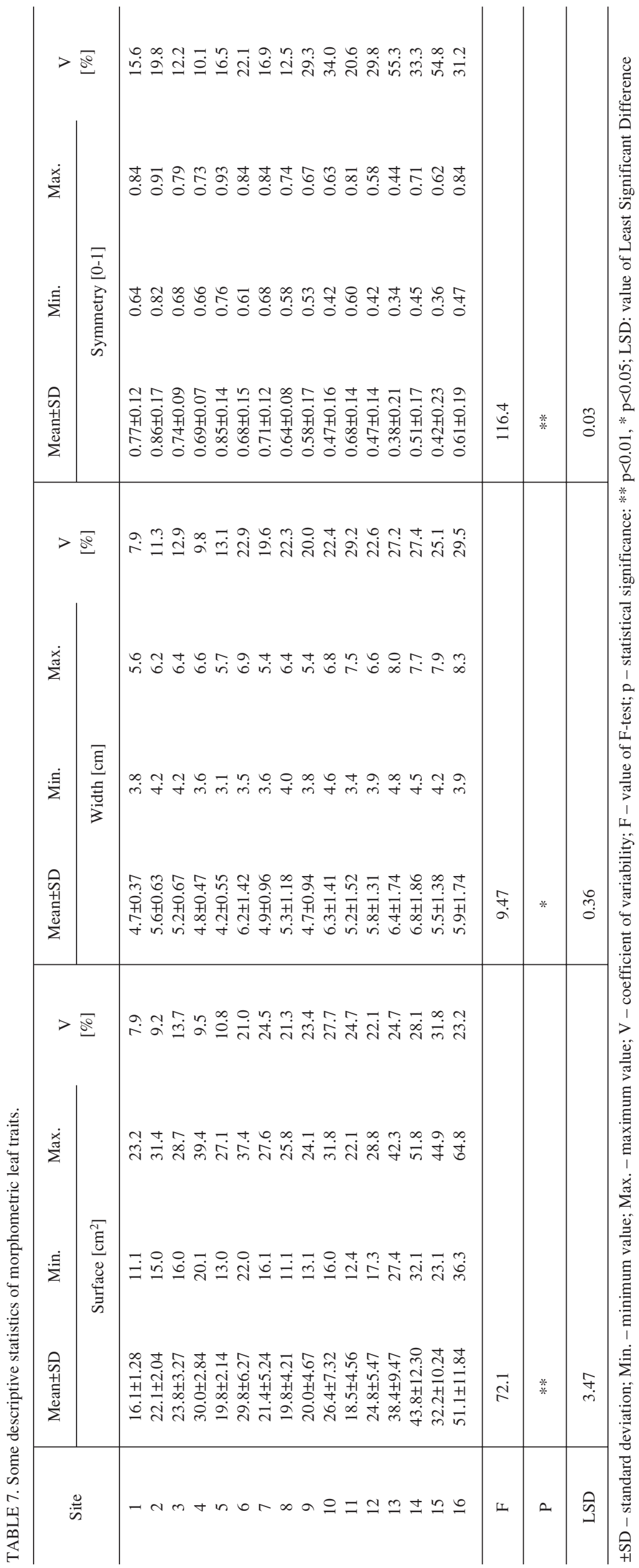

Hence, the average values of surface, width and symmetry of leaves correspond with the ordination of sites in dendrograms, i.e. in respect of metal concentrations in soils (Fig. 3) and in leaves of $T$. cordata (Fig. 4). The larger surface and width of leaves correspond to sites with higher metals concentrations in soils and leaves (6-16), and the lower values on sites not directly subjected to industrial and urban emissions (1-5). Similarly, on polluted sites recorded was the largest asymmetry of leaves, whereas leaves from non polluted sites are less asymmetrical (Fig. 6).

Higher variability coefficients (V) of the analyzed leaf traits occur also in polluted sites. According to Zając (1994), the variability coefficient shows the relation of intensity of additional causes to the main ones. According to Krzywiecka (1989), the variability coefficient up to $5 \%$ describes perfectly the trait's permanency (stability of biometrical trait variability), $\leq 10 \%$ very good, $\leq 15 \%$ good, $\leq 20 \%$ sufficiently, $\leq 25 \%$ insufficiently and over then $25 \%$ wrongly. Thus, it can be stated, that $T$. cordata occurring in polluted sites is characterized by higher values of the variability coefficient in relation to sites not affected by source emissions. One may suppose, that the high and significant differentiation of leaf traits between the sites is the response to pollution of the environment. It was also confirmed in studies of Sierocińska-Jędra (1994), Klein and Paulus (1997) and Kozlov et al. (2002) in the case of other tree species. These authors mention, that the relation of elements concentrations to leaf traits is often used for presentation of the burdening of a plants by chemical compounds. Moreover, investigations of Romero-Schmidt et al. (1995), Mal et al. (2002) Baret et al. (2003), Niinemets and Kull (2003), Tretyakova and Noskova (2004), Gonzalez-Rodrigez and Oyama (2005) show the variability of various morphometric leaf traits and pollens of trees, shrubs and meadow plants, confirming thereby the influence of habitat stress upon traits.

\section{CONCLUSIONS}

The carried out study revealed that Tilia cordata reacts distinctly to the level of environmental pollution with traits such like cationic equilibrium and morphometric traits.

And so, the cationic equilibrium is disturbed by the high air deposit of pollution, i.e. in highly polluted sites the value of cationic equilibrium may show either the lowest or the highest values in relation to the const. (12.515), which is caused by the quality of pollution.

The morphometric traits of leaves show in the same conditions the highest values of sur- 


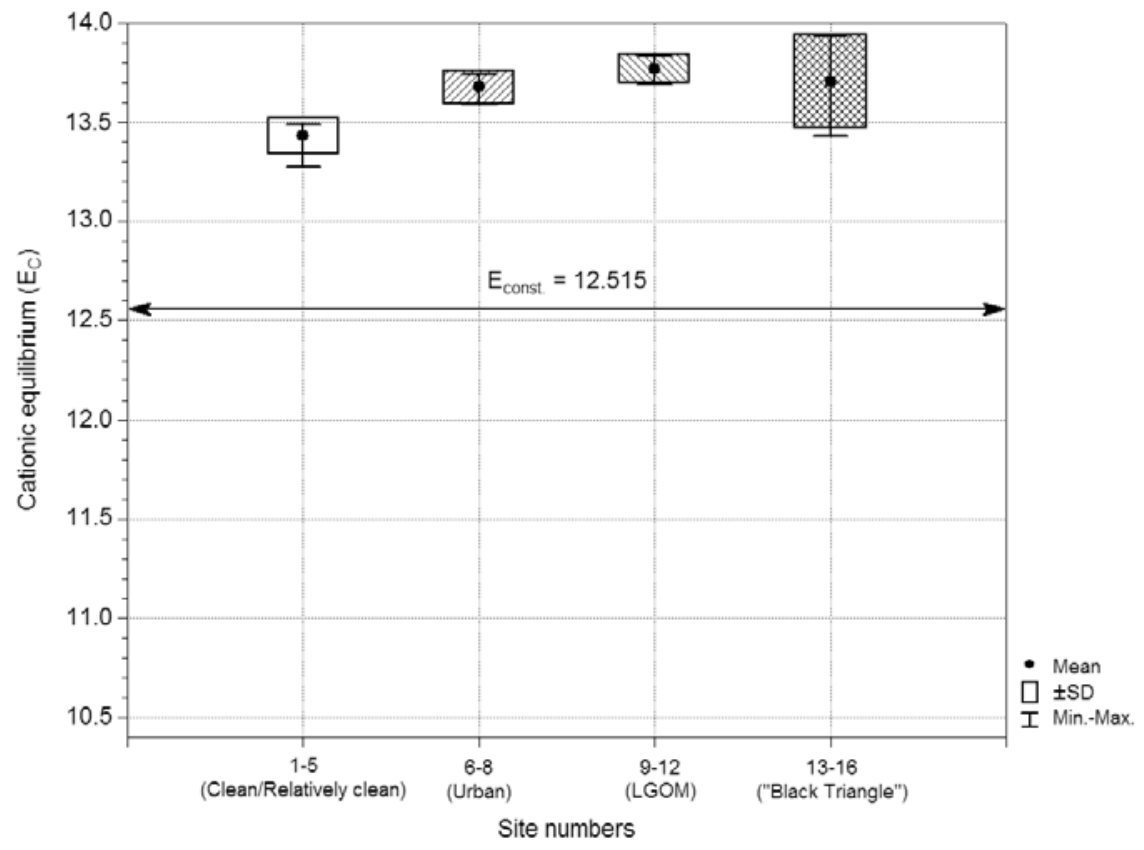

Fig. 5. Variability of estimated cationic equilibrium $\left(\mathrm{E}_{\mathrm{C}}\right)$ in leaves.
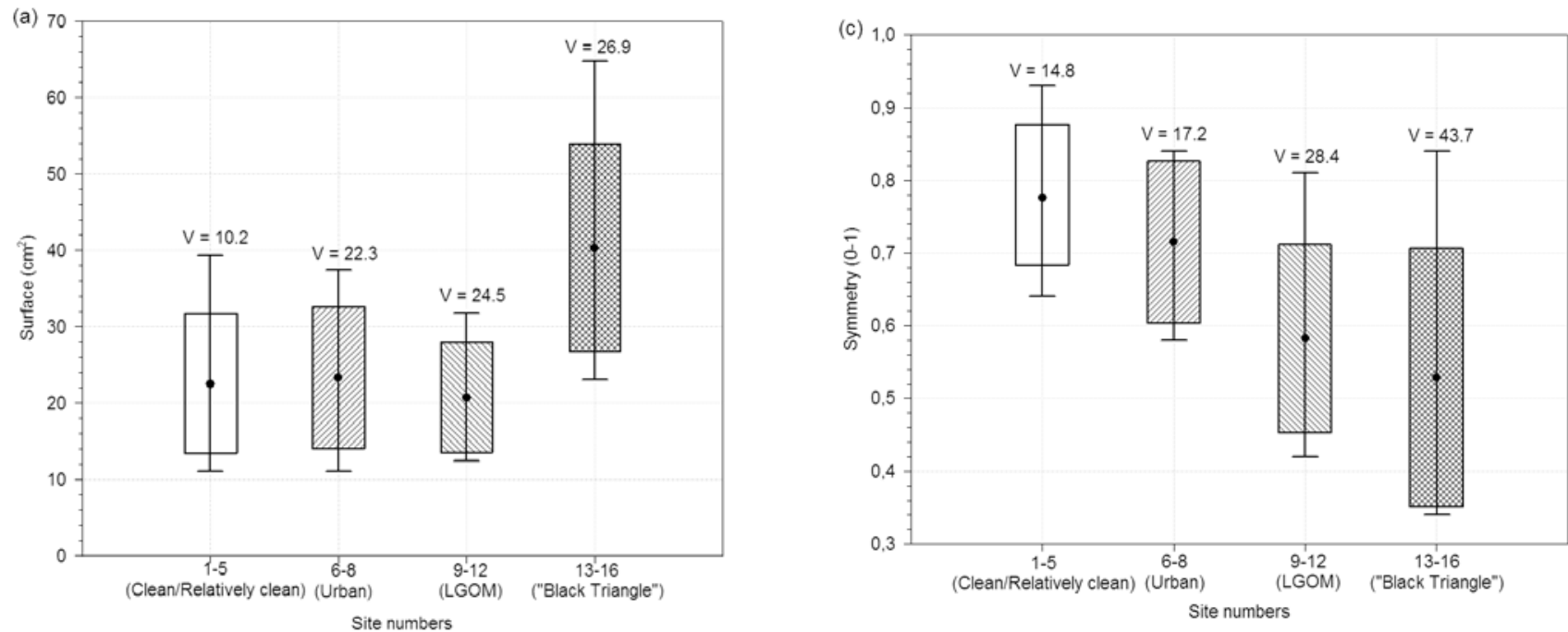

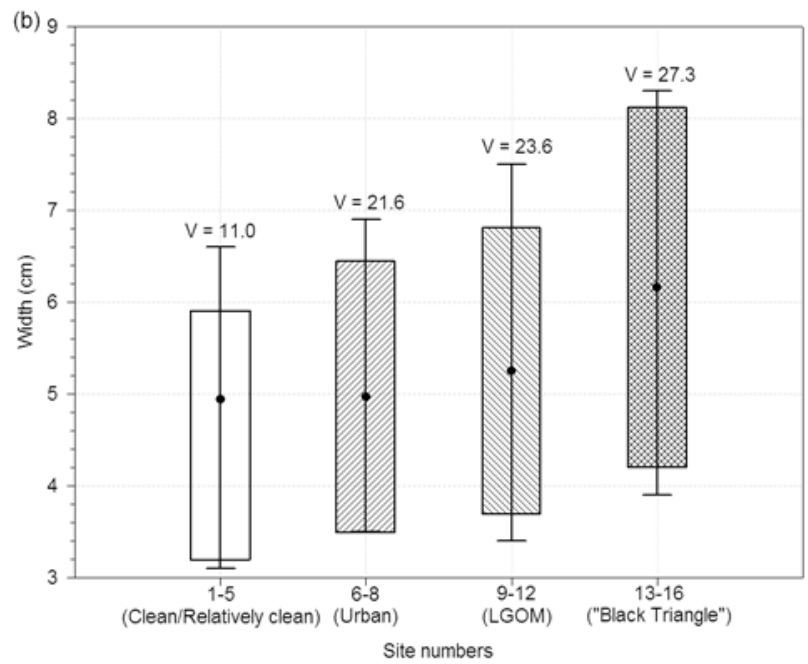

face, width and a greater asymmetry, and are characterized by the highest variability. On the contrary, in sites, which are not directly affected by point-source emitters (clean/re-
Fig. 6. Box-whiskers presentation of the descriptive statistics and variability of morphometric leaf traits between groups (A, B, C and D) of study sites; (a) surface, (b) width, (c) symmetry ( mean; $\square \pm$ SD standard deviation; I Min.-Max. value; V coefficient of variability [\%]).

latively clean) the cationic equilibrium is close to the const. value, whereas leaf traits show the lowest values and a considerably lower variability. 
On the basis of these results, one can say that the presented above traits can be used as a tool for estimation of environmental state, particularly extremely polluted. However, future research should also consider the calibration of plant response along the pollution gradient, effects of other gaseous-dust pollutants, as well as microclimatic conditions, which would give additional information on possibilities of Tilia cordata for biomoitoring.

Of importance is also, the fact that the image and numerical techniques are more precise and practical in ecological studies.

\section{LITERATURE CITED}

ABOAL J.R., FERNANDEZ J.A., CARBALLEIRA A. 2004. Oak leaves and pine needles as biomonitors of airborne trace elements pollution. Environ. Exp. Bot., 51: 215-225.

ALFANI A., BATROLI G., RUTIGLIANO F.A., MAISTO G. VIRZO DE SANTO A. 1996. Trace metal biomonitoring in the soil and the leaves of Quercus ilex in the urban area of Naples. Biol. Trace Element Res., 51, 1: 117-131.

ALLOWAY B.J., AYRES D.C. 1999. Chemiczne podstawy zanieczyszczenia środowiska. PWN, Warszawa (in Polish).

ANTIPOV W.G. 1979. Ustojchiwosc dreviesnykh rastcenijj k promyshlennym gazam. Nauka i Technika, Mińsk.

BACHE C.A., GUTENMANN W.H., RUTZKE M., CHU G., ELFVING D.C., LISK D.J. 1991 Concentrations of metals in grasses in the vicinity of a municipal refuse incinerator. Arch. Environ. Contam. Toxicol., 20, 4: 538-542.

BARET S., NICOLINI W., LE BOURGEOIS T., STRASBURG D. 2003. Developmental patterns of the invasive bramsle $(R u$ bus alceifolius Poiret, Rosaceae) in Reunion island: an architectural and morphometric analysis. Ann. Bot., 91: 39-48.

BARGHIGIANI C., RISTORI T., BAULOEO R. 1991. Pinus as an atmospheric mercury biomonitor. Environ. Technol., 12: 1175-1182.

BATIC F., KALAN P., KRAICHER H., SIRCEJ H., SIMONCIC P., VIDERGAR-GORJUP N., TURK B. 1999. Bioindication of different stresses in forest decline studies in Slovenia. Water, Air Soil Pollut., 116: 377-382.

BELL J.N.B. TRESHOW M. 2002. Air pollution and plant life, 2nd edition. John Wiley \& Sons Ltd. UK.

BIAŁOBOK S. 1991. Lipy, TIlia cordata Mill., Tilia platyphyllos Scop. In: Nasze drzewa leśne, Monografie popularnonaukowe, 15, PAN, Instytut Dendrologii. ARKADIA, Poznań. (in Polish)

BREJ T., FBISZEWSKI J. 2003. Rośliny akumulujące metale ciężkie we florze Sudetów, Ann. Silesiae, 32: 155-163. (in Polish with English summary)

BROWER J.E., ZAR J.H., VON ENDE C.N. 1998. Field and laboratory methods for general ecology. WCB/McGraw-Hill, Boston, Massechusetts Burr Ridge, Illinois Dubuque, Iowa Madison, Wisconsin New York, New York San Francisco, California St. Louis, Missouri.

BYTNEROWICZ A., BADEA O., BARBU I., FLEISCHER P., FRĄCZEK W., GANCZ V., GODZIK B., GRODZIŃSKA K., GRODZKI W., KARNOSKY D., KOREN M., KRYWULT M., KRZAN Z., LONGAUER R., MAŇKOVSKÁ B., MANNING W.J., MC MANUS M., MUSSELAMN R., NOVOTNY J., POPESCU F., POSTELNICU D., PRUS-GŁOWACKI W., SKAWIŃSKI P., SKIBA S., SZARO R., TAMAS S., VASILE C. 2003. New international long-term ecological research on air pollution effects on the Carpathian Mountain forests, Central Europe. Environ. Int., 29: 367-376.

CICEK A., KOPARAL A.S. 2004. Accumulation of sulfur and heavy metals in soil and tree leaves sampled from the surroundings of Tuncbilek Thermal Power Plant. Chemosphere, 57, 8: 1031-1036.
CIECHANOWICZ J. 1994. Ochrona środowiska. Zbiór przepisów. Wydawnictwo Prawnicze LEX, Gdańsk. (in Polish)

CONTI M.E., IACOBUCCI M., CECCHETTI G. 2005. A statistical approach applied to trace metal data from biomonitoring studies. International. J. Environ. Pollut., 23, 1: 29-41.

CORTEX NOVA 2005. DigiShape. Program do automatycznej morfometrii. Cortex Nova, Bydgoszcz, www.cortex.nova.pro.wp.pl (in Polish)

CZARNOWSKI M.S. 1977. Równowaga kationowa w liściach roślin lądowych. Arch. Ochr. Środ., 2: 49-59. (in Polish with English summary)

CZARNOWSKI M.S. 1989. Zarys ekologii roślin lądowych. PWN, Warszawa (in Polish).

DAHMANI-MULLER H., VAN OORT F., GELIE B., BALABANE M. 2000. Strategies of heavy metal uptake by three plant species growing near a metal smelter. Environ. Pollut., 109: 231-238.

DAILY G.C. 1997. What are ecosystem services? In: Nature's Services, Daily G.C. (ed.). Washington, DC, Island Press.

DMUCHOWSKI W., BYTNEROWICZ A. 1995. Monitoring environmental-pollution in Poland by chemical-analysis of Scots Pine (Pinus-Sylvestris L.) needles. Environ. Pollut., 87, 1,87-104.

EMEP STATUS REPORT 2004. Heavy metals: transboundary pollution of the environment, Status Report 2/2004. MCS$\mathrm{E}$ and $\mathrm{CCC}$.

FABISZEWSKI J. (ed.). 1983. Bioindykacja skażeń przemysłowych i rolniczych. PAN, Ossolineum, Wrocław (in Polish).

FABISZEWSKI J., BREJ T. 2000. Contemporary habitat and floristic changes in the Sudety Mts. Acta Soc. Bot. Pol., 69, 3: 215-222.

FABISZEWSKI J., KWIATKOWSKI P. 2002. Threatened vascular plants of the Sudeten Mountains. Acta Soc. Bot. Pol., 71, 4: 339-350.

FABISZEWSKI J., BREJ T., BIELECKI K. 1987. Plant reactions as indicators of air pollution in the vicinity of a copper smelter. Acta. Soc. Bot. Pol., 56, 2: 353-363.

FISHER S., NICHOLAS N.S., SCHEUERMAN P.R. 2002. Dendrochemical analysis of lead and calcium in Southern Appalachian American Beech. J. Environ. Qual. 31: 1137-1145.

GOLDEN SOFTWARE, INC. 2004. Surfer Version 8.03, Surfer Mapping System, Contouring and 3D Surface Mapping for Scientists and Engineers. Golden, Colorado, USA, (www.goldensoftware.com).

GONZALEZ-RODRIGUEZ A., OYAMA K. 2005. Lear morphometric variation in Quercus affinis and $Q$. laurina (Fagaceae), two hybridizing Mexican red oaks. Bot. J. Linn. Soc., 147: 427-435.

HAGEN-THORN A., CALLESEN I., ARMOLAITIS K., NIHLGĹRD B. 2004. The impact of six European tree species on the chemistry of mineral topsoil in forest plantations on former agricultural land. For. Ecol. Manag., 195: 373-384.

HARRISON R.M., CHIRGAWI M.B. 1989. The assessment of air and soil as contributors of some trace metals to vegetable plants. I. Use of a filtered air growth cabinet. Sci. Total Environ., 83, 1-2: 13-34.

HELIOS-RYBICKA E. 1996. Impact o mining and metallurgical industries on the environment in Poland. Appl. Geoch., 11: 3-9.

HERPIN U., BERLEKAMP J., MARKERT B., WOLTERBEEK B., GRODZIŃSKA K., SIEWERS U., LIETH H., WECKERT V. 1996. The distribution of heavy metals in a transect of the three states the Netherlands, Germany and Poland, determined with the aid of moss monitoring. Sci. Total Environ., 187: 185-198.

HONGJIN J., YONGHZENG Z., XISHENG W. 1995. Correspondence cluster analysis and its application in exploration geochemistry. J. Geochem. Explor., 55: 137-144.

HRYNKIEWICZ-SUDNIK J. 1976. Badania i obserwacje nad odpornością drzew i krzewów w świetle ochrony środowiska we Wrocławiu. Rocznik Dendrologiczny, 29: 87-96. (in Polish) 
IANNOTTI O., MINCIGRUCCI G., BRICCHI E., FRENGUELLI G. 2000. Pollen viability as a bio-indicator of air quality. Aerobiologia, 16: 361-365.

KABATA-PENDIAS A., PENDIAS H. 1999. Biogeochemia pierwiastków śladowych. PWN, Warszawa. (in Polish)

KABATA-PENDIAS A. 2001. Trace elements in soils and plants. CRC Press, Boca Raton, FL.

KLEIN R., PAULUS M. 1997. Biometric sample characterization. Part II. The relation between size of needles and concentrations of airborn pollutants. Chemosphere, 34, 9/10: 2015-2021.

KOSIBA P. 1997. Struktura ekologiczna synuzji mszaków pod wpływem skażeń środowiska In: Współczesne kierunki ekologii, Ekologia behawioralna. Materiały z Sympozjum, Lublin 25-26 listopada 1995 roku, Puszkar T., Lucyna Puszkar L. (ed.), Wydawnictwo Uniwersytetu Marii Curie-Skłodowskiej, Zakład Ochrony Przyrody UMCS, Polskie Towarzystwo Ekologiczne, Lublin, Lublin, pp. 307-314. (in Polish with English summary)

KOSIBA P. 2004. Biomonitoring of air and reactions of mosses in conditions of pollution with industry emissions. Acta U. Wratisl., No 2714, Pr. Bot., 80, pp. 109.

KOSIBA P. 2007. Impact of air pollution on the occurrence of Rhytisma acerinium "tar-spot" on maple leaves. Acta Soc. Bot. Pol., 76, 4: 333-343.

KOSIBA P., KOLON K. 2002. Disturbances of ionic equilibrium in mosses of contaminated areas. Acta Soc. Bot. Pol., 71, 4: 323-328.

KOVÁCS M. 1992. Trees as biological indicators. In: Biological indicators in environmental protection. Kovács M. (ed.), Ellis Horwood, New York.

KOZLOV M.V., NIEMENA P., JUNTTILA J. 2002. Needle fluctuating asymmetry is a sensitive indicator of pollution impact on Scots pine (Pinus sylvestris). Ecol. Indicators, 1: 271-277.

KRZYWIECKA M. 1989. Przewodnik do ćwiczeń ze statystyki matematycznej. Skrypt AR we Wrocławiu, No. 347. (in Polish)

KURZYDŁO H. 1994. Lasy Legnicko-Głogowskiego Okręgu Miedziowego, stan aktualny, zagrożenia, przyszłość. Towarzystwo Przyjaciół Nauk w Legnicy, Wydział Nauk Przyrodniczo-Technicznych, Cz. I. Materiały sesji naukowej przygotowanej z Instytutem Dendrologii Polskiej Akademii Nauk w Kórniku, Legnica 24-25 września 1994 r., Oficyna Wydawnicza, Legnica, pp. 98 (in Polish).

KWAPULIŃSKI J., SAROSIEK J. 1988. Radioecotoxicological influence of a power station determined by investigation mosses. Sci. Total Environ., 68: 173-180.

KWAPULIŃSKI J., BOGUNIA M., MIROSŁAWSKI J., SAROSIEK J., HANUS G., KOWALOWSKI P., STOLARCZYK A. 2001. Współwystępowanie wybranych metali w niektórych roślinach na terenie ziemi cieszyńskiej. Acta Univ. Wratisl., No 2317, Pr. Bot., LXXIX, pp. 93-107. (in Polish with English summary)

LEE H.S., LEE K.S., HWANGBO J.K., YOU Y.H., KIM J.H. 2004. Selection of tolerant plants and their arrangement to restore a forest ecosystem damaged by air pollution. Water, Air Soil Pollut., 156: 251-273.

LEGENDRE P., LEGENDRE L. 1998. Numerical ecology. 2nd English edition. Elsevier Science BV, Amsterdam.

LITYŃSKI T., JURKOWSKA H. 1982. Żyzność gleby i odżywianie się roślin. PWN, Warszawa. (in Polish)

MADEJ T. 2002. Gospodarka a środowisko przyrodnicze. Wydawnictwo Naukowe Uniwersytetu Szczecińskiego, Szczecin. (in Polish)

MADEJON P., MARANÓN T., MURILLO J.M., ROBINSON B. 2004. White poplar (Populus alba) as a biomonitor of trace elements in contaminated riparian forests. Environ. Pollut., 132, 145-155.

MAL T.K., UVEGES J.L., TURK K.W. 2002. Fluctuating asymmetry as an ecological indicator of heavy metal stress in Lythrum salicaria. Ecol. Indicators, 1: 189-195.
MARKERT B. 1992. Presence and significance of naturally occurring chemical elements of the periodic system in the plant organism and consequences for future investigations on inorganic environmental chemistry in ecosystems. Vegetatio, 103: $1-30$.

MARKERT B. (ed.) 1993. Plants as Biomonitors, Indicators for Heavy Metals in the Terrestrial Environment. VCH Press, Weinheim.

MARKERT B., HERPIN U., SIEWERS U., BERLEKAMP J., LIETH H. 1996. The German heavy metal survey by means of mosses. Sci. Total Environ., 182: 159-168.

MARSCHNER H. 1995. Mineral nutrition of higher plants. Academic Press. Harcourt Brace \& Company, Publishers, London-San-Diego-New York-Boston-Sydney-Tokyo-Toronto.

MASSARD D.L., KAUFMAN L. 1983. The interpretation of analytical chemistry data by the use of cluster analysis. John Willey \& Sons, New York.

MENGEL K., KIRKBY E.A. 2001. Principles of plant nutrition. Kluwer Academic Publisher. Dordrecht, The Netherlands.

MORENO-SANCHEZ M. 2004. Graphic approach for morphometric analysis of Archaeopteris leaves. Annls. de Paleontologie, 90: 161-173.

NABAIS C., FREITAS H., HAGEMEYER J. 1999. Dendroanalysis: a tool for biomonitoring environmental pollution? Sci. Total Environ., 232, 1-2: 33-37.

NIINEMETS U., KULL K. 2003. Leaf structure vs. nutrient relationships vary with soli condition in temperate shrubs and trees. Acta Oecologica, 24: 209-219.

PREMOLI A.C., 1996. Leaf architecture of South American Nothofagus (Nothofagaceae) using traditional and new methods in morphometrics. Bot. J. Linn. Soc., 121: 25-40.

RAPORT 2006. Raport o Stanie Środowiska w Województwie Dolnośląskim w 2005 roku. Inspekcja Ochrony Środowiska, Wojewódzki Inspektorat Ochrony Środowiska we Wrocławiu, Biblioteka Monitoringu Środowiska, Wrocław. (in Polish)

ROMERO-SCHMIDT H., CADENA R.D., ORTEGA-RUBIO A. 1995. Morphometric variations among three populations of the endemic Behria tenuiflora (Alliaceae) in Baja California Sur, Mexico. J. Arid Environ., 31: 77-81.

SALEMAA M., DEROM J., HELMISAARI H.S., NIEMINEN T., VANHA-MAJAMAA I. 2004. Element accumulation in boreal bryophytes, lichenes and vascular plants exposed to heavy metal and sulfur deposition in Finland. Sci. Total Environ., 324: 141-160.

SAMECKA-CYMERMAN A. 1988. Interakcje kationów w Scapania undulata (L.) Dum. Arch. Ochr. Środ., 3-4: 127-133. (in Polish with English summary)

SAMECKA-CYMERMAN A., MARCZONEK A., KEMPERS A.J. 1997. Bioindication of heavy metals In soil by liverworts. Arch. Environ. Con. Tox., 33, 2: 162-171.

SAMECKA-CYMERMAN A., KEMPERS A.J., KOLON K. 2000. Concentrations of heavy metals In aquatic bryophytes used for biomonitoring in rhyolite and trachybasalt areas: a case study with Plathhypnidium rusciforme from the Sudety Mountains. Ann. Bot. Fennici, 37: 95-104.

SAWICKA-KAPUSTA K., ZAKRZEWSKA M., BAJOREK K., GDULA-ARGASIŃSKA J. 2003. Input of heavy metals to the forest floor as a result of Cracow Urban pollution. Environ. Int., 28, 691-698.

SAWIDIS T., MARNASIDIS A., ZACHARIADIS G., STRATIS J. 1995 A study of air-pollution with heavy-metals in Thessaloniki City (Greece) using trees as biological indicators. Arch. Environ. Con. Tox., 28, 1: 118-124.

SENETA W. 1987. Dendrologia. PWN, Warszawa. (in Polish)

SENETA W., DOLATOWSKI J. 2005. Dendrologia. PWN, Warszawa. (in Polish)

SIEROCIŃSKA-JĘDRA A.M. 1994. Zmienność parametrów biometrycznych liści klonu pospolitego (Acer platanoides L.) jako wskaźnik jego wrażliwości na warunki miejskie w Warsza- 
wie. In: Rekacje biologiczne drzew na zanieczyszczenia przemysłowe. III Krajowe Sympozjum Kórnik, 23-26 maja 1994, Wyd. Sorus, 355-361. (in Polish with English summary)

SHPARYK Y.S., PARPAN V.I. 2004. Heavy metal pollution and forest Heath In the Ukrainian Carpathians. Environ. Pollut., 130: $55-63$

SKINDER W.N. 1991. Chemia a ochrona środowiska. WSiP, Warszawa. (in Polish)

SPENCER S. 2001. Effects of coal dust on species composition of mosses an lichenes in an arid environment. J. Arid Environ., 49: 843-853.

SPOREK K. 1995. Wpływ imisji przemysłowych na plonowanie roślin ze szczególnym uwzględnieniem sosny zwyczajnej. Oficyna Wydawnicza OIKOS sp. z o.o., Warszawa, pp. 46. (in Polish with English and German summary)

STATSOFT, INC. 2005. STATISTICA (data analysis software system), version 7.1, StatSoft, Inc., Tulsa, OK, USA, (www.statsoft.com).

SOKAL R.R., ROHLF F.J. 2003. Biometry. The principles and practice if statistics in biological research. W.H. Freeman and Company, New York.

TRETYAKOVA I.N., NOSKOVA N.E. 2004. Scotch pine pollen under condition of environmental stress. Russian J. Ecol., 35, 1: $20-26$.
WALKER C.H., HOPKIN S.P., SIBLY R.M., PEAKALL D.B. 2005. Principles of ecotoxicology, Taylor \& Francis, London, UK.

WYTTENBACH A., BAJO S., TOBLER L. 1990. Major and trace elements in spruce needles by NAA. In: Schrauzer G.N. (ed.) Biological trace elements research. Humana Press, Clifton, United Kingdom, pp. 213-221.

YILMAZ S., ZENGIN M. 2004. Monitoring environmental pollution in Erzurum by chemical analysis of Scott pine (Pinus sylvestris L.) needles. Environ. Int., 29: 1041-1047.

ZAJĄC K. 1994. Zarys metod statystycznych. PWE, Warszawa. (in Polish)

ZAKRZEWSKI S.F. 1995. Podstawy toksykologii środowiska. PWN, Warszawa. (in Polish)

ZAR J.H. 1999. Biostatistical analysis. Prentice Hall, Upper Saddle River, New Jersey.

ZELDITCH M.L., SWIDERSKI D.L., SHEETS H.D., FINK W.L. 2004. Geometric morphometrics for biologists: A Primer. Elsevier Academic Press, London. 